Two new Generic Types of the Families Saprolegnieæ and Peronosporeæ. By MM. E. RozE and M. Connu.

The authors remark that it is questionable whether the Saprolegnieæ should be referred to the algæ or the fungi. They think that one of their new genera furnishes an argument in favour of the latter. It is an endophyte, parasitic upon the smallest of our phanerogams, Wolffia Michelii, Schleid. (Lemna arrhiza, Linn.), and presents some characters belonging both to the Saprolegnieæ and Peronospores, so that it may to a certain extent be regarded as intermediate between the two families. They name it Cystosiphon pythioides.

Its mycelium, which traverses the cells of the Wolffia by perforating their walls, developes the two kinds of reproductive organs (sexual and asexual) which have already been indicated in the species of this family. The first mode of reproduction terminates in the formation of an oospore, the thick epispore of which resembles that of the oospores of the Peronosporeæ. This oospore originates here, however, from the fertile union of the antheridian and oogonic plasma, effected by means of a short process emitted by the antheridium, which penetrates into the oogonial cavity.

The so-called asexual reproduction of Cystosiphon is effected by means of zoosporangia. These are represented by vesicles which terminate certain branches of the mycelium in peripheral cells of the Wolffic. When mature, each of these vesicles, which is isolated by a septum from the rest of the mycelium, emits a tube which runs perpendicularly to meet the cellular wall separating it from the water. This flattens itself against the cellulose membrane, which it perforates by an exosmotic action, and then grows out into the water until its extremity becomes stationary and slightly thickened. The plasma of the zoosporangium is then instantaneously diffused in this extremity of the tube in the form of a plastic spheroid, which in a few minutes contracts and shows a very delicate enveloping membrane continuous with the tube. The following phenomena are then rapidly witnessed in the interior of this vesicle :-A network of clcar lines indicates the segmentation which takes place in the plasmic mass, and the cilia appear; the segments separate from each other and constitute the zoospores; these agitate their cilia, and move more and more rapidly; lastly a portion of the wall of the resicle becomes absorbed and the zoospores escape. Their movements last for about half an hour; they then become spherical, lose their cilia, become clothed with a membrane, and germinate by emitting a tube. This germinative tube then penetrates by perforation into the cells of healthy fronds of Wolffia, where it is developed into a mycelium.

The Peronosporeæ, to which the second new generic type belongs, have hitherto included only the genera Cystopus and Peronospora. The endophytal fungus, parasitic on Erigeron canadense, Linn., described by the authors under the name of Basidiophora entospora, is distinguished at the first glance from the above genera hy its 
conidiophorous stipites, which resemble the basidia of the Hymenomycetes.

The conidia, or asexual reproductive organs of Basidiophora, when placed in water at their maturity, present the remarkable fact that their plasma, instead of being expelled before the complete formation of the zoospores, undergoes its whole sporogonic evolution within them. The zoospores move in the conidia until the apical papilla of the latter, becoming absorbed, leaves them a passage into the liquid. This aperture, however, being much too narrow for the free passage of the zoospores, they pass it, one after the other, with great difficulty, by lengthening and twisting themselves with a most singular power of vitality. After their escape they traverse the liquid with considerable rapidity, but in less than an hour they stop and germinate.

The organs of sexual reproduction in Basidiophora are formed in the parenchyma of the leaves which have already presented the conidiophorous stipites. But this parenchyma, being formed by a very compact cellular tissue, does not allow us to ascertain clearly the relations of the antheridia and oogonia, or to observe the phases of fecundation.-Comptes Rendus, March 15, 1869, tome Ixviii. pp. $651-653$.

\section{On Spatangus Raschi, Lovén.}

At the meeting of Scandinavian naturalists at Christiania, in July 1868, Prof. Lovén exhibited specimens of this new species, which was first discovered on the deep sea-bank of Storegzen, off the coast of Norway, as far back as 1844, by Prof. H. Rasch, of the University of Christiania. Since that time it has been found occasionally in the same locality, and Mr. Gwyn Jeffreys has dredged it in the Zetland seas. From the Spatangus purpureus of O. F. Müller, which it almost surpasses in size, it differs by its more oblong and posteriorly more attenuated form and greater height, by much narrower petala, by the flattened ventral surface, the prominent lip, the narrow strongly keeled sternum, of almost equal breadth throughout, and by the rounded, not bilobate, area semitalis, half as large as that of Spatangus purpureus of the same size. The colour is dark reddish browa; and the primary spines, arranged, as in $S p$. purpureus, in arcuate series, are shorter than in that species.

At the same time, Prof. Lovén drew attention to the fact that, in very young specimens of Spatangidæ, the peristomium, situated much nearer the middle of the body than in the full-grown animal, is exactly pentagonal, with the mouth, an oval opening in its centre, surrounded by perforated plates of an irregular form. But the mouth is very soon drawn backwards, and becomes transversely elongated, the surrounding plates assuming their specific shapes; and when the mouth has reached the posterior side of the peristomial pentagon, this side begins to protrude forwards and to develope into the vaulted lip peculiar to the Spatangidæ. This juvenile pentagonal form of the peristomium is retained by the full-grown individual in Palceostoma and in certain fossil forms, as Echinospatangus, Holaster, and others.-Communicated by Prof. Lovén. 